plex. Though too much weight must clearly not be given to such negative evidence, the possibility should be considered that at North Berwick, Upper Palaeozoic sediments directly overlie a gneissic basement complex. The biotite-rich mafic and ultramafic clasts are probably genetically related to the basanitic magmas the degassing of which was responsible for the drilling of the vent.

The discovery of gneissic blocks at North Berwick lends support to the views expressed by Kennedy ${ }^{3}$ and George ${ }^{4}$ that the Dalradian Basin was bounded to the south by a Precambrian landmass underlying the Midland Valley and the region further south. In north-western Ireland, upper Dalradian (mid-Cambrian) turbidites could have been derived $^{5}$ from an uplifted basement of amphibolite and granulite facies lying to the south-east, of which the Deer Park Complex formed a part. Church and Gayer ${ }^{\circ}$ also considered that some of the Connemara metamorphic rocks could represent exposures of a sialic basement to the Midland Valley structural unit. The concept of continental crustal rocks underlying the Southern Uplands and their Irish (Longford Down) continuation has both geological and geophysical support ${ }^{2,7,8}$ and the new observations from Partan Craig would seem to confirm that a high-grade metamorphic complex also underlies at least a portion of the Midland Valley. It is difficult to reconcile the presence of these gneissic clasts with the various models proposed by Jeans $^{9}$, Gunn ${ }^{10}$ and Mitchell and McKerrow ${ }^{11}$, in which postArenig formations of the Midland Valley are postulated to overlie an earlier Palaeozoic oceanic crust.

B. G. J. UPTON

P. ASPEN

A. Graham

Department of Geology,

University of Edinburgh,

Edinburgh EH9 $3 \mathrm{JW}, \mathrm{UK}$

Department of Earth Science,

N. A. Chapman

University of Leeds,

Leeds L52 9JT, UK

Received January 8; accepted February 26, 1976.

1 Chapman, N. A., J. Petrol. (in the press).

2 Strogen, P., Nature, 250, 562 (1974)

3 Kennedy, W. Q., Trans. geol. Soc. Glasg., 23, 106 (1958).

4 George, T. N. Trans. geol. Soc. Glasg., 24, 32 (1960)

5 Phillips, W. E. A., J. geol. Soc. Lond.. 129, 585 (1973).

6 Church, W. R., and Gayer, R. A., Geol. Mag., 110, 497 (1973).

7 Phillips, W. E. A., Stillman,C. J., and Morphy, T., Abstr. XII Meeting of European Geological Societies (1975)

8 Powell, D. W., Scott. J. Geol., 7, 369 (1971).

9 Jeans, P. J. F., Nature phys. Sci., 245, 120 (1973).

10 Gunn, P. J., Nature, 242, 111 (1973).

11 Mitchell, A. H. G., and McKerrow, W. S., Bull. geol. Soc. Am., 86, 305 (1975).

\section{Cromagnon in the Iron Gate Gorge of the Danube}

Radiocarbon datings on human skeletons from the Padina site in the Iron Gate Gorge of the Danube in Yugoslavia have revealed that they belonged to a population at least $9,000 \mathrm{yr}$ old. This age is of especial importance because it is the earliest yet obtained by radiocarbon analysis for human bones from the region. It indicates for the first time the existence of a Cromagnon population in Yugoslavia.

During excavations at Padina ${ }^{1}$, the remains of 37 individual skeletons, all in a very bad state of preservation, were uncovered. Anthropological study and laboratory examinations have shown that the skeletons possess all the morphological characters of the Cromagnon racial type. The skulls are long with huge supraorbital ridges and low vaults and the jaws are very large, with very rough areas for muscular attachments and with large prominent ridges and spines. The bones of the limbs are also large and robust with strongly marked muscular imprints. The average esti- mated height of the male individuals is approximately $180 \mathrm{~cm}$ (ref. 2).

Bone tissue for the analysis reported here came from the upper end of the best-preserved femora obtained. The specimens came from the lowest geological layer of the excavations. So far, two dates have been obtained: $6,487 \pm 83$ yr b.c. (BM1144); and 7,248 \pm 103 yr b.c. (BM1147).

The Padina population lived in arc-like hollows beside the river bank which was intersected by rocky ridges and surrounded by wooded cliffs. Alterations in the course of the river destroyed several such settlements, and gravely impaired the state of preservation of the human remains.

The excavations are into early Holocene deposits $(\sim 10000-6000 \mathrm{BC})$. At that time the climate, flora and fauna, and the general terrain and geography of Yugoslavia, became similar to those of the present day. The permanent snow cover of the Dinaric mountains melted, and grassland-bringing with it wild wheat, oats, barley and ryespread along the Danubian plain. Wild goats, pigs, cattle and deer inhabited the forest ${ }^{3}$. It is very probable that in this region some Pleistocene hunters and gatherers adapted themselves to the new climatic conditions and migrated along the Danube, which offered them a new source of food. Fishing became as useful as gathering and hunting.

Archaeological finds and cultural remains at Padina (and other sites such as Hajdučka, Vodenica, Lepenski Vir and so ${ }^{1}$ have not previously provided suitable material for accurate dating, although a radiocarbon date of $4,950 \mathrm{yr}$ b.c. has been obtained from charcoal from the floor of one of the houses at Lepenski Vir (British Museum Radiocarbon Laboratory). Recently, similar material from Vlasac (not very far from Padina), examined at the Radiocarbon Laboratory in Zagreb has given a date of 5,609 $\pm 93 \mathrm{yr}$ b.c. (ZG 267); until this report, that was the earliest estimated age for these populations.

It is expected that further excavations further down the River Danube in the near future will reveal more human material in a better state of preservation, thus enabling a more detailed study of this newly discovered Cromagnon population.

I am grateful to the British Museum Research Laboratory for performing the ${ }^{14} \mathrm{C}$ analysis, and to the Radiocarbon Committee for financial support. I also thank the Institute of Archaeology in Belgrade, Yugoslavia, for providing the financial support for the field work and anthropological study.

\section{S. Zivanovic}

Department of Anatomy,

St Bartholomew's Hospital Medical College,

Charterhouse Square,

London ECIM 6BQ, UK

Received January 23; accepted February 26, 1976.

1 Jovanović, B., Arheol. Pregled, 10, 89-91 (1968); Archaeologia Iugoslavica, 10, 23-38 (1969).

2 Zivanović, S., Z. Morph. Anthrop., 66, 161-175 (1975).

Alexander, J., Jugoslavia Before the Roman Conquest (Thames and Hudson. London, 1972).

\section{Effect of sewage sludge on mineralisation of organic carbon in soil}

SOME $40 \%$ of the sludge produced at inland sewage works in England and Wales is applied to agricultural land ${ }^{1}$. In addition to the plant nutrients and organic matter they provide, such sludges also contain various quantities of heavy metals ${ }^{2}$. In some cases, repeated and very heavy dressings of sludge have led to accumulations of harmful elements that are toxic to plants ${ }^{3}$. There has been concern about their possible accumulation in agricultural soils receiving sludge 